\title{
PARTICULARITIES OF MARKETING COMMUNICATIONS IN THE FIELD OF INTERNATIONALIZATION OF HIGHER EDUCATION IN THE RUSSIAN FEDERATION
}

\author{
Svetlana G. PYANKOVA ${ }^{\mathrm{a}}$, Inna V. MITROFANOVA ${ }^{\mathrm{b}, \mathrm{c}}$, Olga T. \\ ERGUNOVA $^{\mathrm{d}}$, Marina E. BUYANOVA ${ }^{\mathrm{c}}$ \\ ${ }^{a}$ Ural State Economic University, Department of Regional, Municipal Economics and Management, \\ Ekaterinburg, Russia. E-mail: silen_06@list.ru \\ ${ }^{\mathrm{b}}$ Federal Research Centre the Southern Scientific Centre of the Russian Academy of Sciences (SSC RAS), \\ Laboratory of Regional Economics, Rostov-on-Don, Russia. E-mail: mitrofanova@volsu.ru \\ c Volgograd State University, Department of Economic Theory, World and Regional Economics, \\ Volgograd, Russia. E-mail: mitrofanova@volsu.ru; buyanovame@volsu.ru \\ ${ }^{\mathrm{d}}$ Ural State University of Economics, Department of Tourism Business and Hospitality, Ekaterinburg, \\ Russia. E-mail: ergunova-olga@yandex.ru
}

Cite this article: Pyankova, S. G., Mitrofanova, I. V., Ergunova, O. T., Buyanova, M. E. (2021). Particularities of marketing communications in the field of internationalization of higher education in the Russian Federation. Deturope, 13(3), 98-117.

\begin{abstract}
The relevance of this research is determined by the need for scientific substantiation of the use of advertising and PR-technologies in the field of higher education in order to improve the management of the university in the international educational services market. Over the past ten years, the market for educational services has changed significantly: new agents and training formats have appeared, competition between universities for consumers has increased, the requirements of employers for the level and quality of education of graduates have changed significantly. Global and local market conditions are constantly changing and thus create a difficult to predict environment. In this regard, they need to develop an effective advertising and PR strategy to create competitive advantages. The development and implementation of effective advertising and PR activity requires an individual approach that takes into account the specifics of the educational institution and, above all, the specifics of the market in which they operate.

The purpose of the study is to conduct a comparative analysis of the use of advertising and PR technologies used by universities in Russia on the basis of the obtained results the development of recommendations on advertising and PR technologies for the effective functioning of Russian universities on the international market of educational services. To achieve this goal, the following tasks were formulated: to study the features of advertising and PR technologies in the market of educational services; to identify relevant communication technologies used by the university in the work with the target audience.

The research methodology includes the following set of empirical methods: analysis of websites of Russian on such criterions as informativeness, usability, website design, functionality and location in search results; content analysis of accounts of Russian on social networks listed on the official website of the universities with a relevant link. For the study, Russian universities included in QS World University Rankings 2020 were selected, they were classified into 4 groups: National universities with the status of "unique scientific and educational complexes, the country's oldest universities, of great importance for the development of Russian society", National Research universities are awarded for a ten-year term on a competitive basis with the aim of creating on their basis advanced world-class research and educational centers, Federal universities and Flagship, regional universities.
\end{abstract}

Keywords: advertising and PR technologies, international market, educational services, university, social networks, website, foreign students, graduates. 


\section{INTRODUCTION}

The relevance of this research is determined by the need for scientific substantiation of the use of advertising and PR-technologies in the field of higher education in order to improve the management of the university in the international educational services market. Any higher education institution aims to occupy a high market share by offering various types of educational services. Russia is no exception among universities around the world that are fighting seriously for the right to educate foreign students who are profitable for both universities and the country, as well as strengthening the image of national education in the international market. According to the UNESCO Institute for Statistics, Russia with a share of $5 \%$ of world student mobility, along with France and Germany is among the six countries in attractiveness for foreign students, behind the USA (19\%), Great Britain (8\%) and Australia (7\%). According to the data indicated in the analytical report of official website on higher education in Russia for foreigners studyinrussia.ru Russian universities are popular in the same states, the largest number of foreign students in Russia is from the CIS countries, Asia (Afghanistan, India, China, Mongolia, Turkey, etc.). Stable interest in Russian education is maintained in countries of Europe (Germany, Italy, France, Hungary, Bulgaria, etc.), America and Latin America (USA, Canada, Brazil, etc.), the Middle East (Israel, Jordan, Syria, etc.) and Africa (Algeria, Egypt, Nigeria, South Africa, etc.). Thus, we choose universities of Russia for a comparative analysis of advertising and PR technologies. Taking into account the wide variety of university communication tools and the characteristics of the main target audience, our study is more focused on online communication, namely the use of the official website and maintaining accounts on popular social networks, as an effective tool for interaction between universities and the target audience, play an important role in managing image and reputation of the university in the face of fierce competition in the national and global educational market.

The aim of the article is conducting a comparative analysis of the use of advertising and PR technologies used by universities in Russia and on the basis of the obtained results the development of recommendations on advertising and PR technologies for the effective functioning on the international market of educational services.

\section{LITERATURE OVERVIEW, MATERIALS}

The changes in the operating conditions of state and private enterprises and organizations, the economy and society have led to a demand for educational services. According to many 
researchers the market of educational services also has several specific features (Table 1) that distinguish them from other types of services which are also important for the proper application of advertising and PR technologies in practice.

Table 1 The specifics of educational services

\begin{tabular}{|c|c|}
\hline $\begin{array}{l}\text { The feature of } \\
\text { educational service }\end{array}$ & The description of the feature \\
\hline $\begin{array}{l}\text { Long lasting nature of } \\
\text { services }\end{array}$ & $\begin{array}{l}\text { Getting the first higher education in various specialties can take from } 4 \\
\text { years }\end{array}$ \\
\hline Service Licensing & $\begin{array}{l}\text { The state acts as a judge in the market of educational services, issuing } \\
\text { licenses for the right to conduct educational activities and establishing the } \\
\text { state accreditation status of an educational institution, according to which } \\
\text { a university has the right to issue state-issued diplomas (Cordelier, } \\
\text { Vasquez \& Viviane (2021) }\end{array}$ \\
\hline $\begin{array}{l}\text { Competitive nature of } \\
\text { education }\end{array}$ & $\begin{array}{l}\text { Most universities provide education on a competitive basis, i.e. a consumer } \\
\text { who wants to use the services of a university will be provided only if he } \\
\text { has certain knowledge, skills that are available through tests, examinations } \\
\text { or interviews (Constantinides \& Stagno, 2011) }\end{array}$ \\
\hline High price & $\begin{array}{l}\text { Educational services are expensive because they are actively building up } \\
\text { the potential of the individual, specialist, and in developed markets this is } \\
\text { expressed in legitimacy of high prices for them (Kaushal \& Ali, 2019). }\end{array}$ \\
\hline $\begin{array}{l}\text { Delayed performance } \\
\text { identification }\end{array}$ & $\begin{array}{l}\text { A peculiar feature of educational services is the impossibility of their } \\
\text { direct monetary measurement. The price mechanism is often not able to } \\
\text { reflect all the costs of producing educational services. The useful result of } \\
\text { such a service can appear only after a long time, and it can practically be } \\
\text { measured only with the help of indirect indicators (Ong, Lee \& Ramayah, } \\
\text { 2018) }\end{array}$ \\
\hline $\begin{array}{l}\text { The feature of } \\
\text { educational service }\end{array}$ & The description of the feature (Simon \& Tossan, 2018). \\
\hline $\begin{array}{l}\text { The ambiguity of the } \\
\text { goals set for the } \\
\text { producers of these } \\
\text { services. }\end{array}$ & $\begin{array}{l}\text { As a rule, the activities of an educational institution are not explicitly } \\
\text { aimed at achieving profit. But, on the other hand, many of their interests } \\
\text { are associated with the growth of welfare, which involves «making a profit } \\
\text { necessary to ensure expanded reproduction» (Potdar, Joshi, Harish, } \\
\text { Baskerville \& Wongthongtham, 2018). Therefore, profit is not an initially } \\
\text { forbidden reference point for educational institutions, but, of course, it } \\
\text { does not come down to it alone (Prentice, Wang \& Loureiro, 2019) }\end{array}$ \\
\hline
\end{tabular}

An important feature of the promotion of educational services on the market is that advertising is realized both during and after consumption (Simon, Brexendorf \& Fassnacht, 2013, Yoshida, Gordon, Nakazawa, Shibuya \& Fujiwara, 2018). 
The high importance of PR tools in promoting a university and the increasing role of PR in the higher education system are due to the fact that PR helps to solve the problem of expanding the educational space of a university and its integration into the world educational space. Strydom, Jooste, and Cant (2000) define public relations as management through communication or perception, and the strategic relationship between an organization and its internal and external public. Public relations can be defined as a deliberate, planned and sustained efforts to establish or to maintain mutual and understanding between the institute and the customers to develop core values of the institute (Ashirbagina \& Frick, 2016). This may be in between; staff-alumni, institute-alumni, staff-schools and teachers, institute-schools and teachers or institute-community (Bocharov \& Chumikov, 2014; Levina, 2015). It creates, develops and maintains positive image of the institute which is very effective tool of promotion in era of competition. Institute do arrange social programs like health and medical campus, cleanliness drive, tree plantation, computer literacy programs to develop public relation with the community.

Various types of exhibitions are one of PR tools. They provide the opportunity for personal contact with potential consumers and the distribution of advertising information in print (Salgado \& Vela, 2019). Salamatov et al. (2012) finds a number of advantages in the participation of the university in exhibitions:

Maintaining the image of the university for both broad groups of the public and target audiences (Shahsavar \& Sudzina, 2017).

Providing a wide corporate message with a large number of people at the same time combined with the possibilities of personal communications (Chapleo, 2015).

The possibility of direct interaction with potential consumers (Salamatov et al., 2012).

Interactive events such as workshops, career counseling, lotteries with prizes in the form of corporate souvenirs help to attract as many visitors to your corner as possible, increase loyalty to the university (Levina, 2015).

At higher education institutions the effectiveness of the use of Internet resources depends on the focused work to promote the educational services of the university. It is also important to realize that the promotion of educational services should be carried out in conjunction with the positioning of the university as a producer of an educational product, as well as with measures to support the image and recognition of the university's brand (Belyavsky, 2014). Speaking about Internet marketing it is necessary to note other key elements in promoting a university on the Internet. 
Each university, using its website, blog on popular social networks aim to position itself as a higher educational institution, which: provides students with the opportunity to receive a full competitive education that meets modern requirements; creates the conditions for the student research activities; provides students with excellent living condition (Neretina \& Makarets, 2009).

Social media platforms in relation to education, it is an Internet marketing tool aimed at promoting educational services and the university's brand which allow to interact with the target audience (Belousenko, 2018). Approximately 2 billion Internet users are using social networks and these figures are still expected to grow as mobile device usage and mobile social networks increasingly gain traction. The most popular social networks usually display a high number of user accounts or strong user engagement (Freberg, 2020). The chart, prepared by the Statista analytical agency, gives a clear idea of the number of active users (in millions) in the most popular social networks worldwide as of May 2020 is showed in Fig. 1.

Figure 1 Most popular social networks worldwide

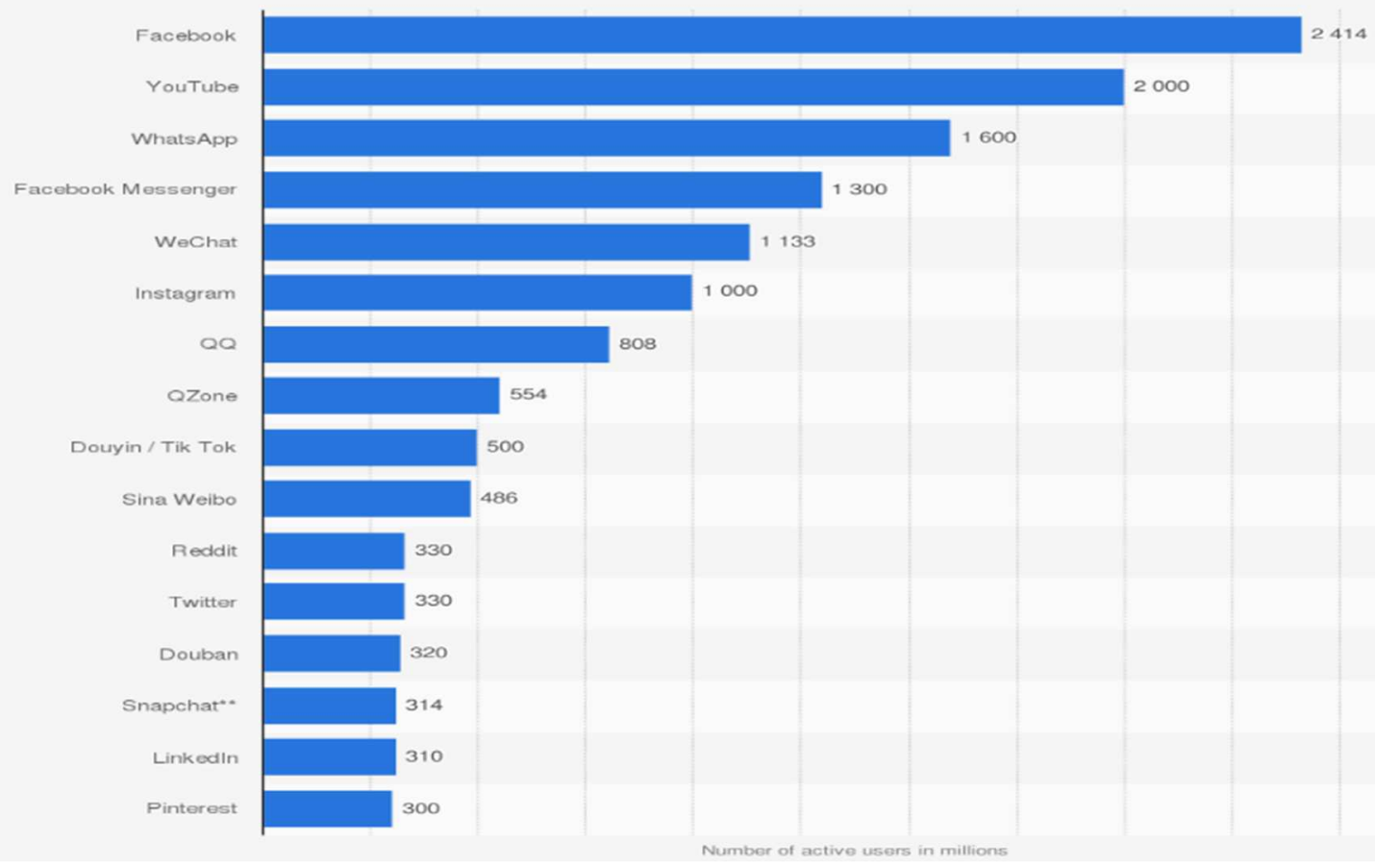

Source: Most popular social networks worldwide as of July 2021, ranked by number of active users(in millions) // https://www.statista.com/statistics/272014/global-social-networks-ranked-by-number-of-users/

It is quite important to be aware of how to behave and what publications to do on social networks, as it forms the image of the university's brand and, as a result, stimulates followers to buy educational services or, on the contrary, unsubscribe from the account. 
Issues of internationalization are among the priorities in the strategic development of universities, along with the development of science and education. According to García and Villarreal (2014), international students provide an additional income stream for educational institutions and contribute to the economy of their host country. The result of the increasing involvement of higher education institutions in the system of market relations is the desire for the financial well-being of the institution. Attracting foreign students also affects prestige, high ratings and competitiveness. In their work, Yuzhakova and Karakchieva (2015, p. 35) note: "The number of foreign students is one of the most important indicators in the rankings of universities in the global market for educational services, which determines their success". Melikyan (2016) also indicates the importance of the presence and number of foreign students at the university in compiling international ratings: "The number of foreign students studying at the university is one of the indicators of external evaluation of the university's performance and is taken into account win the process of compiling international university ratings, which encourages universities to develop this area".

The accelerated dynamics of world educational processes, globalization, the creation of international educational projects lead to the need to create conditions and implement the processes of internationalization of universities in all countries seeking to internationally position higher education. In the study of Schulz (2006), the process of building interaction with potential university students is considered in the game concept, where, as in any game, there are certain strategies and techniques necessary to achieve a winning position. Therefore, the strategy of working with applicants should be based on a clear understanding of their requests and flexible adaptation to selection factors (Jess, 2019).

A review of the activities of universities in attracting students shows that concentrating on recruiting is not enough for a student to choose a particular university. Thus, the interaction of universities with foreign students using various tools can be divided into three stages: recruiting, integration during studying, after graduation. Arseniev, Belyaevskaya, Denisova and Vrublevskaya (2016) claim in their work that recruitment of foreign students is the process of finding, attracting, selecting and enrolling students in a university. It should be noted that the first stage of working with foreign students begins long before they enter the university, for example, at the stage of active participation of the university in international educational exhibitions in order to inform applicants in other countries, as well as to present all the benefits of studying in this particular university (Mahoney, 2013, Shurair \& Pokharel, 2019, Sim, Conduit, \& Plewa, 2018). 
It should be noted that the placement of information about programs on the websites of partner universities, associations, organizations and blogs, as well as the active exchange of cross-links can also become one of the most significant channels for attracting foreign students (Clement, 2020).

According to experts, significant benefits from work with recruiting agencies are available and for educational organizations, and for students in Tab. 2.

Table 2 Benefits from work with recruiting agencies

\begin{tabular}{|l|l|}
\hline \multicolumn{1}{|c|}{ Benefits for educational organizations } & \multicolumn{1}{|c|}{ Benefits for students } \\
\hline $\begin{array}{l}\text { Agencies represent universities throughout the } \\
\text { calendar year }\end{array}$ & $\begin{array}{l}\text { Presence of a reliable, competent and responsible } \\
\text { representative of the university in the country of } \\
\text { origin of the student (Altschwager, Dolan, \& } \\
\text { Conduit, 2018) }\end{array}$ \\
\hline $\begin{array}{l}\text { Dissemination of advertising information, } \\
\text { conducting targeted campaigns in the media, } \\
\text { participating in student exhibitions and open } \\
\text { days for schoolchildren }\end{array}$ & $\begin{array}{l}\text { Giving consultation to students and their parents } \\
\text { in their own language, which is especially } \\
\text { important when choosing long-term programs } \\
\text { (Qiao, Song \& Wang, 2019) }\end{array}$ \\
\hline $\begin{array}{l}\text { Providing reliable information about the state of } \\
\text { regional educational market }\end{array}$ & $\begin{array}{l}\text { Offering the optimal place and direction of study } \\
\text { in accordance with the interests of the student } \\
\text { and the features of universities (Carvalho, \& } \\
\text { Fernandes,2018) }\end{array}$ \\
\hline Providing access to regional infrastructure & $\begin{array}{l}\text { Providing useful additional services such as } \\
\text { filling out registration forms, insurance, tickets, } \\
\text { visas (Goi, Kalidas, \& Yunus, 2018) }\end{array}$ \\
\hline $\begin{array}{l}\text { Help in promotion programs that are in low } \\
\text { demand }\end{array}$ & $\begin{array}{l}\text { Offering support throughout the process } \\
\text { enrollment and training by agents (Farhat, } \\
\text { Mokhtar \& Salleh, 2021) }\end{array}$ \\
\hline $\begin{array}{l}\text { Increasing the ratio of successful receipts to the } \\
\text { submitted applications }\end{array}$ & $\begin{array}{l}\text { Providing student feedback upon completion } \\
\text { learning }\end{array}$ \\
\hline
\end{tabular}

Building relationships with foreign graduates can attract applicants to the university. Reviews and recommendations of students and graduates are one of the most effective tools that influence decision making in favor of choosing this or that educational institution (Rodríguez, Román \& Zúñiga-Vicente, 2019). It is necessary to attract foreign students after graduation as experts in the educational process on various issues, for example, as jury members at various educational and other student contests, to defend projects within the educational project and 
other activities. Such close cooperation will allow foreign students to leave only positive impressions about this university (Pimonova \& Fomina, 2018).

\section{METHODS}

The entry of Russia into the global educational space has made these countries need to create an agreed strategic plan for the development of higher professional education (Alcaide-Pulido, Alves \& Gutiérrez-Villar, 2017, Butkouskaya, Llonch-Andreu \& Alarcón-Del-Amo, 2019, Ivanova \& Mironova, 2012, Prentice, Wang \& Loureiro, 2019).). Speaking about the integration of Russian higher professional education into the world educational space, it is necessary to especially note the role of the Bologna process, uniting 48 countries with different political, cultural and academic traditions, which, step by step during the last twenty years, built an area implementing a common set of commitments: structural reforms and shared tools Russia joined the Bologna process in September 2003 at the Berlin meeting of European education ministers. Russian higher education has transferred to a two-cycle system. So, according to the Federal law "On education in the Russian Federation", the following 2 steps can be distinguished:

1) higher education includes 4 years of Bachelor programme and 2 years of Master programme;

2) postgraduate education consists of three (four for certain subject areas) years for full-time doctoral programme (aspirantura) and $\mathrm{PhD}$ programme.

Today, a huge role is played not by the number of universities, but by their position in world rankings. Cowan G., Arsenault A. note that only a developed education system that meets the requirements of innovative high-tech economy and is integrated into the international educational and scientific space, can become one of the major competitive advantages of the modern state in the «global competition for minds» and attract the most talented foreign students (Arsenault \& Cowan, 2008, Elken, 2019). The provision of educational opportunities for foreign students is one of the most important instruments of soft power of the state (Guilbault, 2018, Kerr \& Kelly, 2017).

States are interested in developing special programs aimed at improving the quality of the higher education system and to strengthen and enhance the position of their universities in international rankings. Thus, the government of the Russian Federation introduced the project "5-100". The Project was launched by the Russian Ministry of Education and Science on the 
basis of a statement from Vladimir Putin on 7 May 2012 "On measures for the implementation of state policy in the education and science field". The goals of Project "5-100" are to maximize the competitive position of a group of leading Russian universities in the global research and education market and bring at least five universities from among the project participants into the hundred best universities according to the world university rankings. The 21 participants of Project "5-100" which receive government support were chosen through a two-stage process. According to the information on the official website of the project, the main results expected of Project "5-100" by 2020 are that Russia will have a group of leading contemporary universities with an effective management structure, and a strong international academic reputation which meets global development trends and can quickly adapt to global changes.

According to the Federal Law of December 29, 202 No. 273-Ф3 (as amended on March 7, 2018) "On Education in the Russian Federation", foreign applicants are entitled to study in Russia both on the basis of international agreements of the Russian Federation and intergovernmental agreements at the expense of the Russian budget (including the established quota), as well as under contractual agreements when paying for the cost of studying by an individual and/or legal entity. There are three options of getting education at Russian universities agreements at the expense of the Russian budget:

- to become the winner of Russian and specialized Olympiads which are annually approved by the Ministry of Education and Science of Russia;

- to pass the unified state exam (USE) or entrance exams;

- to pass competitive selection for state scholarships (quota), which provides 15,000 places for free studying for foreign citizens. Competitive selection for free studying under the quota is organized by 95 representative offices Rossotrudnichestvo in 80 states of the world.

If we look at the data on foreign students in Russia for 2018/2019 indicated in Tab. 3, we can see the prevailing number of foreign students in Russia from the same countries from where they come to Kazakhstan. The choice of studying at Russian universities by foreign students from other regions is determined by the satisfaction of foreign students with the variety of educational programs, the material and technical condition of universities and the ratio of price and quality of Russian education. 
Table 3 Number of foreign students at Russian and Kazakhstan universities

\begin{tabular}{|l|l|l|}
\hline $\begin{array}{l}\text { Regions of citizenship of foreign } \\
\text { students }\end{array}$ & $\begin{array}{l}\text { Number of foreign } \\
\text { students at } \\
\text { universities }\end{array}$ & $\begin{array}{l}\text { Number of foreign students } \\
\text { at Kazakhstan universities }\end{array}$ \\
\hline CIS countries & 136090 & 12973 \\
\hline Asia & 64621 & 5649 \\
\hline Europe & 11884 & 63 \\
\hline America and Latin America & 5339 & 28 \\
\hline Middle East countries & 22180 & 77 \\
\hline African countries & 14589 & 19 \\
\hline
\end{tabular}

Source: Education and Science (2020)

A large influx of students from the CIS countries is explained by the preservation of knowledge of the Russian language and, therefore, the possibility of learning in it. As it is known the most common language of communication is one of the important factors when choosing a country of study. Also, Russia, seeking to increase the competitiveness of their higher education systems in the context of internalization, increase the number of educational programs taught in English.

The research methodology includes the following set of empirical methods: analysis of websites of Russian on such criterions as informativeness, usability, website design, functionality and location in search results; content analysis of accounts of Russian on social networks listed on the official website of the universities with a relevant link.

To carry out the analysis of university websites, we have selected Russian universities included in QS World University Rankings 2020 (Tab. 4) and have been classified in to four groups:

1) National universities with the status of «unique scientific and educational complexes, the country's oldest universities, of great importance for the development of Russian society»: Lomonosov Moscow State University (MSU); Saint-Petersburg University (SPbU);

2) National Research universities are awarded for a ten-year term on a competitive basis with the aim of creating on their basis advanced world-class research and educational centres: Novosibirsk State University (NSU); Tomsk State University (TSU); Bauman Moscow State Technical University (BMSTU);

3) Federal are created by combining several regional universities into one and strengthening the ties of universities: Ural Federal University named after the first President of Russia B. N. Yeltsin (UrFU); Kazan Federal University (KFU); Far-Eastern Federal University (FEFU); 
4) Flagship universities are regional universities - Novosibirsk State Technical University (NSTU).

Table 4 The positions of Russian universities in QS World University Rankings 2020

\begin{tabular}{|l|l|l|l|l|l|l|l|l|}
\hline Rank & University & $\begin{array}{l}\text { Overall } \\
\text { score }\end{array}$ & $\begin{array}{l}\text { Citations } \\
\text { per } \\
\text { faculty }\end{array}$ & $\begin{array}{l}\text { Interna- } \\
\text { tional } \\
\text { students }\end{array}$ & $\begin{array}{l}\text { Interna- } \\
\text { tional } \\
\text { faculty }\end{array}$ & $\begin{array}{l}\text { Faculty } \\
\text { student }\end{array}$ & $\begin{array}{l}\text { Employer } \\
\text { reputation }\end{array}$ & $\begin{array}{l}\text { Academic } \\
\text { reputation }\end{array}$ \\
\hline 84 & $\begin{array}{l}\text { Lomonosov } \\
\text { Moscow } \\
\text { State } \\
\text { University }\end{array}$ & 63.2 & 7.2 & 56.1 & 18 & 99.7 & 84.9 & 73.6 \\
\hline 231 & $\begin{array}{l}\text { Novosibirsk } \\
\text { State } \\
\text { University }\end{array}$ & 39.8 & 16.4 & 49.1 & 11.6 & 93.8 & 26.4 & 30 \\
\hline 234 & $\begin{array}{l}\text { St. } \\
\text { Petersburg } \\
\text { State } \\
\text { University }\end{array}$ & 39.6 & 6 & 35.8 & 6.9 & 87.9 & 31.3 & 38.6 \\
\hline 268 & $\begin{array}{l}\text { Tomsk State } \\
\text { University }\end{array}$ & 36.5 & 4.5 & 88.9 & 23.4 & 99.8 & 17.3 & 20.5 \\
\hline 284 & $\begin{array}{l}\text { Bauman } \\
\text { Moscow } \\
\text { State } \\
\text { Technical } \\
\text { University }\end{array}$ & 35.1 & 1.2 & 12.4 & 8.5 & 100 & 53.4 & 21 \\
\hline 364 & $\begin{array}{l}\text { Ural Federal } \\
\text { University }\end{array}$ & 30.4 & 2.1 & 34.7 & 15.7 & 94 & 14.6 & 17.7 \\
\hline 392 & $\begin{array}{l}\text { Kazan } \\
\text { Federal } \\
\text { University }\end{array}$ & 28.5 & 3.5 & 53.1 & 9.7 & 82.3 & 8 & 18.2 \\
\hline $531-$ & $\begin{array}{l}\text { Far-Eastern } \\
\text { Federal } \\
\text { University }\end{array}$ & - & - & 45.8 & 18.7 & 79.9 & - & - \\
\hline $801-$ & $\begin{array}{l}\text { Novosibirsk } \\
\text { State } \\
\text { Technical } \\
\text { University }\end{array}$ & - & - & 44.8 & - & 26.5 & - & \\
\hline
\end{tabular}

After analysing the website on informativeness criteria, we can make conclusion that the websites of nine Russian universities match the informativeness criterion as for all the groups of analysed target audience (Digital 2019, 2020).

However, in the English version of the websites of KFU, NSTU there is no necessary information for graduates. The information presented on the websites is relevant and easy to perceive. Information on the sites is easily perceptible due to the readability of the text, highquality video and photos. All universities, without exception, timely update the information on the site: the news feed is full of current news about the activities of the university, the achievements of the university and its students, employees, about past events both within the 
university and outside it, as well as announcements of upcoming events. For the convenience of using a newsfeed the universities use filters by date, by topic news. Sorting news by topics is similar, mostly about science, events, achievements, local and international students, cooperation, sport, culture, innovations, education. Universities are trying to make their sites more user-friendly by introducing elements to improve perceptibility of information and better understand implications. As a result of comparing the sites on usability we can note the navigation for all the sites is quite understandable and consistent.

\section{RESULTS}

All the universities except Kazan Federal University have set the version for visually impaired on the sites in Russian. BMSTU has it on the site in English, too. MSU, TSU and UrFU have the version for visually impaired in both Russian and English version. Thus, by installing elements such as a sitemap, a search form university allow users to have quick access to the desired information without having to browse through all sections, taking into account the user's time and efforts, which also increases website usability. For effective communicative interaction with visitors, the main thing is to comply with the feedback principle. Universities provide different types of communication elements not limited to indicating contact numbers, mail, addresses and links to accounts on various social networks. For example, MSU, SPbU, BMSTU and KFU offer to contact the Rector of the heads of University departments using their Internet reception by sending a letter (Pyankova, Mitrofanova, Ergunova, \& Zhemerikina, 2020).

According to multilingualism, three leaders can be distinguished: KFU is the absolute leader by presenting its official website in nine languages, then UrFU with five languages. MSU, $\mathrm{SPbU}$, NSU, TSU have their sites in three languages: Russian, English and Chinese. The websites of BMSTU, FEFU and NSTU work in two languages: Russian and English. It is noteworthy that universities not only translate content into the declared foreign language, but also localize it by posting data relevant to foreign citizens and skipping Russian news.

It is a well-known fact that Web design is important because it affects how the audience perceives the brand. The impression that the site reproduces on them can make them stay on the website and get more information or leave the site and contact a competitor. We also have analysed the Russian universities on functionality and entered the data in Tab. 5. 
Table 5 Russian universities in search results

\begin{tabular}{|c|c|c|c|c|c|c|c|c|c|c|c|c|c|c|c|c|c|}
\hline \multicolumn{18}{|c|}{ Location in search results for keywords } \\
\hline $\begin{array}{l}\text { Keywor } \\
\text { d }\end{array}$ & \multicolumn{4}{|c|}{ Uni in Russia } & \multicolumn{4}{|c|}{$\begin{array}{l}\text { The best university in } \\
\text { Russia }\end{array}$} & \multicolumn{4}{|c|}{$\begin{array}{l}\text { Top Russian universities } \\
2020\end{array}$} & \multicolumn{4}{|c|}{$\begin{array}{lll}\text { World } & \text { university } & \text { rankings } \\
\text { Russia } & & \end{array}$} & \multirow[t]{2}{*}{$\begin{array}{l}\text { The } \\
\text { average }\end{array}$} \\
\hline $\begin{array}{l}\text { Search } \\
\text { engine }\end{array}$ & $\begin{array}{l}\text { Go } \\
\text { ogl } \\
\text { e }\end{array}$ & $\begin{array}{l}\mathrm{Bi} \\
\text { ng }\end{array}$ & $\begin{array}{l}\text { Ya } \\
\text { ho } \\
\text { o }\end{array}$ & $\begin{array}{l}\text { Ya } \\
\text { nde } \\
x\end{array}$ & $\begin{array}{l}\text { Goo } \\
\text { gle }\end{array}$ & $\begin{array}{l}\mathrm{Bi} \\
\text { ng }\end{array}$ & $\begin{array}{l}\text { Ya } \\
\text { hoo }\end{array}$ & $\begin{array}{l}\text { Yan } \\
\text { dex }\end{array}$ & $\begin{array}{l}\text { Goo } \\
\text { gle }\end{array}$ & $\begin{array}{l}\mathrm{Bi} \\
\text { ng }\end{array}$ & $\begin{array}{l}\text { Ya } \\
\text { hoo }\end{array}$ & $\begin{array}{l}\text { Yan } \\
\text { dex }\end{array}$ & $\begin{array}{l}\text { Goog } \\
\text { le }\end{array}$ & $\begin{array}{l}\mathrm{Bi} \\
\text { ng }\end{array}$ & $\begin{array}{l}\text { Yaho } \\
\text { o }\end{array}$ & $\begin{array}{l}\text { Yande } \\
\mathrm{x}\end{array}$ & \\
\hline MSU & 5 & 8 & 28 & - & 58 & 62 & - & - & - & - & - & - & 43 & - & - & - & 34 \\
\hline$\overline{\mathrm{SPbU}}$ & 11 & - & 11 & - & 45 & - & - & - & 44 & - & - & - & 45 & 10 & 30 & - & 28 \\
\hline NSU & 50 & - & - & - & - & - & - & - & - & - & 44 & - & 21 & - & - & - & 38.3 \\
\hline TSU & 16 & 42 & 98 & - & - & - & - & - & - & - & - & - & - & - & - & - & 52 \\
\hline BMSTU & 93 & 0 & 0 & - & - & - & - & - & - & - & - & - & - & - & - & - & 93 \\
\hline UrFU & 54 & 23 & 37 & 51 & - & - & - & - & 100 & - & - & - & - & - & - & - & 53 \\
\hline KFU & 26 & 36 & - & 50 & 91 & - & - & - & - & - & - & - & - & - & - & - & 50.75 \\
\hline FEFU & 32 & 33 & 80 & - & - & - & - & - & - & - & - & - & - & - & - & - & 48.3 \\
\hline NSTU & 64 & 6 & - & 73 & 64 & - & - & 77 & - & - & - & 75 & - & - & - & 78 & 52.7 \\
\hline
\end{tabular}

All the sites without exception completely pass the criterion of cross-browser compatibility and layout stability. The sites of all nine universities are adapted for mobile version. But there are significant differences in loading speed of the sites. SPbU, UrFU and BMSTU have relatively low speed - more than 3 seconds. The highest loading speed belongs to Kazan Federal University (1.89). The speed of the other sites ranges from 1.93 to 2.24 seconds. The speed of loading sites is within acceptable range.

Universities are currently active to promote themselves and form their positive image through social networks. The following social networks are popular with Russian universities: Facebook, Instagram, YouTube, VK and Twitter (Fig. 2).

Figure 2 Russian universities on social networks

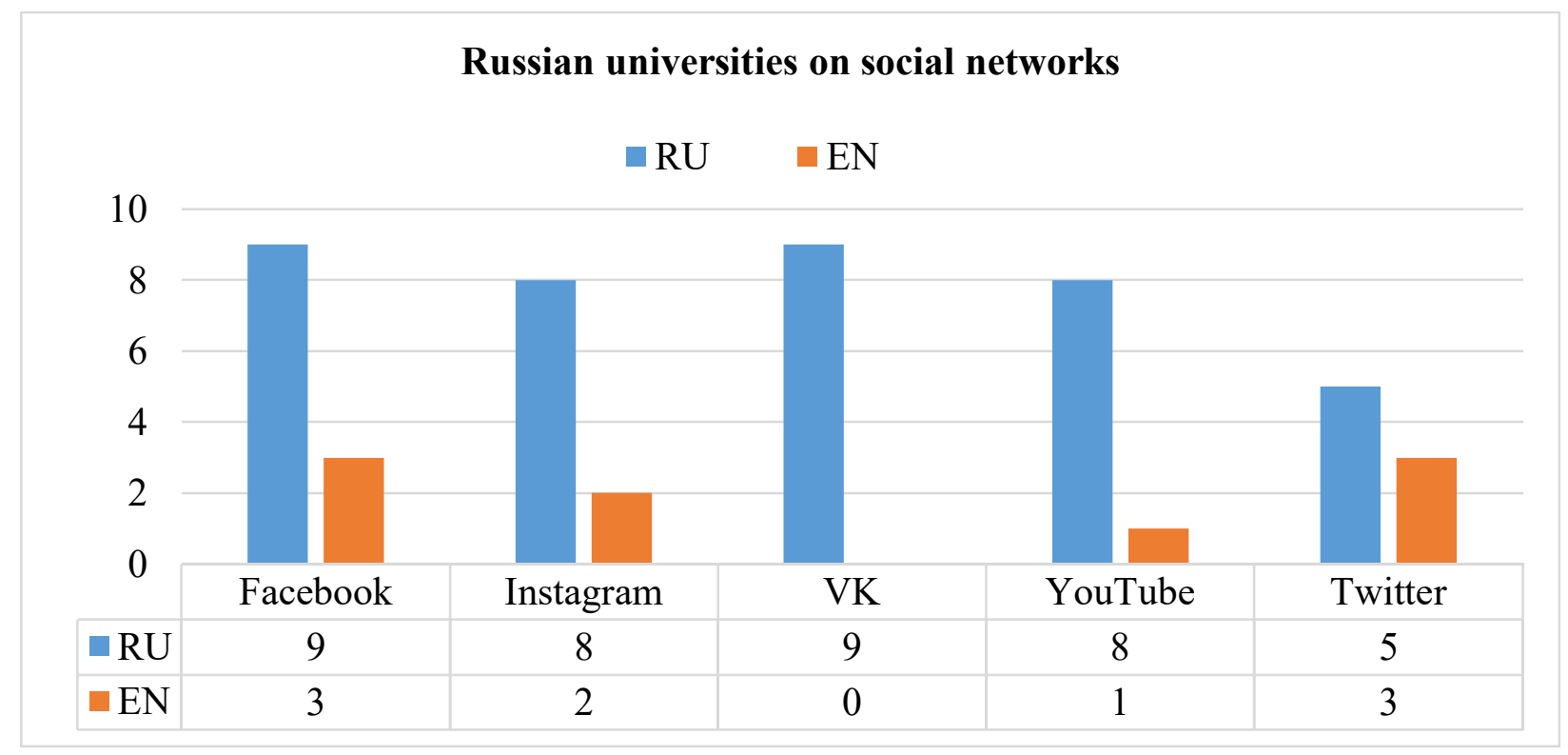

Source: Korchagova (2019) 
The number of Facebook subscribers ranges from 562 to 51273, where Moscow State University (51273), UrFU's account in English (9096) and Far-Eastern Federal University (7314) are among the top three. From December 19, 2019 to January 19, 2020, the universities published posts ranging from 6 to 92.92 published posts belong to UrFU's account in Russian. MSU and NSTU published the equal number of posts (65). BMSTU has the least number of posts - only six.

Thus, we can conclude that Russian universities are active in all three stages of working with students using online communication tools as an official website and social networks, as well as offline through a series of events involving student organizations. However, the full potential of effective online channels was not affected, since significant shortcomings were found in the use of the site during its analysis, and the inefficiency or even lack of a strategy for maintaining accounts on social networks manifested as a low level of user engagement. Another important area requiring great efforts and attention at these sites is communication with graduates. Since not all universities provide information for this target audience on their websites and social networks.

\section{RECOMMENDATIONS}

We suggest applying the following online forms as ways to establish more effective communication with people interested in educational services of russian universities on the international market for educational services:

1) A form to book Skype consultation with a representative of admissions committee, indicating the date and time;

2) A form for registration to use the opportunity to be a student at the russian universities for a day, indicating.

The second method requires the participation of current active students to jointly attend lectures and practical classes, present student organizations, and tour the campus (Huempfner $\&$ Kopf, 2017). In these forms, users must specify an email address, which contributes to the creation of a customer base for the successful use of email marketing.

The content of the sections for "Graduates" differs in the Russian and English versions of the site. The Russian-language version of the «Graduates» section more fully informs about the activities of the Alumni Association and its units, about projects and events with the participation of graduates and for them, awards. We recommend describing the most successful employment examples of both local and foreign graduates in the format of video presentations 
on their behalf. Such section does not function in the English version, but it is recommended to create it because the indicated types of data can positively affect the decision of applicants and increase the prestige of the university.

As we know (Kaushal \& Ali, 2019), various interactive elements on a site are the most attractive and contribute to a more memorable and easily perceived content compared to static alternatives. For example, it is recommended that russian universities, various interactive elements on a site are the most attractive and contribute to a more memorable and easily perceived content compared to static alternatives. For example, it is recommended that UrFU, in sections for applicants or graduates, provide statistical data on the employment of graduates of UrFU at all levels and educational programs in detail using updated static infographics using multimedia interactivity elements. Installed filters by educational level and educational programs and navigation buttons will allow users to receive the information requested by them. The embodiment of this project also requires maintaining communication with graduates and conducting questionnaires for graduates on an ongoing basis. Tests are one of the simplest forms of interactive content that Russian universities can use as an aid to applicants and enrolled students in determining their interests and propensities for anticipated employment.

Users of social networks interested in a university would also be interested in the experience of educational and extracurricular activities of current students, as they are the most reliable source of information for applicants and the ability to speak the same language increases the confidence of the audience (Chapleo \& O'Sullivan, 2017). For this mission, active students of Russian universities who want to gain practical skills in social media marketing or attract subscribers to their account can act as virtual guides, giving an idea of what everyday student life looks like, where the audience of the account can see the class process, interacting both with teachers and students, demonstrate events or even the process of preparing for the event. For the purpose of this type of content, live videos do a great job in stories, live broadcasts. Real-time exchange and interaction on social platforms are at the peak of popularity, so active work and interaction with their subscribers can be a great way to implement the above described plan.

Game content on social networks launches mechanisms and tools that build two-way interaction between the author and subscribers. Tests are one of the simplest forms of interactive content that Russian universities can use as an aid to applicants and enrolled students in determining their interests and propensities for anticipated employment. According to the results of the passed test, students will receive practical recommendations and will be able to study several proposed student organizations operating at Russian universities. Thus, we will 
be able to engage in the activities of Russian universities in an entertaining way and create a positive emotional connection with the brand.

Also, students and employees of Russian universities can participate in global challenges adapting for their purpose, distributed on the expanses of social networks. Today, the trend challenge is flip the switch, which the university can adapt to its own style and even attract the rector of the university, showing the path of the applicant to the graduate receiving a diploma from the Rector. Participating in such events, Russian universities clearly show how they support the initiatives and ideas of students and try to be on the same wavelength with the audience. Given the popularity of videos on TikTok, perhaps Russian universities should start acting on one of the trending platforms for interacting with a young audience. Another advantage of the site is the principle of "repeat after all", which makes it easy to catch trends and speak the same language with the target audience.

\section{CONCLUSION}

The research methodology includes the following set of empirical methods: analysis of websites of Russian on such criterions as informativeness, usability, website design, functionality and location in search results; content analysis of accounts of Russian on social networks listed on the official website of the universities with a relevant link; QS World University Rankings 2020.

The analysis of the features of integration communications in the field of the internationalization of higher education in the Russian Federation allowed us to conclude that the large number of universities and the diversity of their educational programs taught in both Russian and English, providing several ways of getting education on a budgetary basis. RF has a budget education system for people who are not citizens of Russia. According to interviews with employees of departments of universities in Russia, universities use similar tools for working with applicants (Open Doors Days, participation in educational exhibitions, international conferences, organization of field information sessions), students (assistance in paperwork and settling in a dormitory with representatives of buddy, organization of the Orientation Week, campus tour, etc.) and graduates (assistance in finding employment, creating an association of graduates, invitation to participate in university events). However, they note the high efficiency of online communication.

The official websites of universities and their accounts on social networks were selected as online communication, to which users can go from the site through a link-transition. As a result 
of the analysis, we can conclude that universities in Russia may not understand the full potential of these online resources, since they do not use them in full. During the analysis, significant shortcomings of sites were revealed, namely, insufficient information content of the site for the selected group of the target audience, the absence or limited functioning of interactive tools, the presence of irrelevant sections and links. Universities will have to work on Search Engine Optimisation of their websites, as their low position in search results, and in most cases a complete absence, is noted. The most popular social networks with Russian are Facebook, Instagram, Vkontakte, YouTube and Twitter. In this sector, one can also highlight a number of shortcomings affecting the effective communication activities of the university.

Among the analysed Russian universities there are universities whose positive experience in maintaining accounts can be adopted. Since they create content using modern trends, for example, sharing of user-generated content, the publication of interactive and entertaining posts, the placement of useful information. The main problem of the activities of universities on social networks is the low level of user engagement, expressed in the number of likes, comments, and shares which also affects the position of the university's site in search results. Therefore, universities will have to develop an effective communication concept for maintaining their accounts that meets the needs and interests of users.

As a result of the study, we can conclude that in connection with the entry of universities into the global market for educational services, the use of advertising and PR technologies in accordance with the needs, wishes and expectations of the target audience and the overall development strategy of the university are necessary and quite effective tools for the implementation of competitive activities of universities and the formation of university brand and its positive image.

\section{Acknowledgement}

The publication was prepared as part of the implementation of the State Assignment of the Southern Scientific Centre of the Russian Academy of Sciences, No. of state registration of the project AAAA-A19$119011190184-2$.

\section{REFERENCES}

Alcaide-Pulido, P., Alves, H., \& Gutiérrez-Villar, B. (2017). Development of a model to analyze HEI image: A case based on a private and a public university. Journal of Marketing for Higher Education, 27(2), 162-187.

Altschwager, T., Dolan, R., \& Conduit, J. (2018). Social brand engagement: How orientation events engage students with the university. Australasian Marketing Journal, 26(2), 8391. 
Arsenault, A., \& Cowan, G. (2008). Moving from Monologue to Dialogue to Collaboration: The Three Layers of Public Diplomacy. The ANNALS of the American Academy of Political and Social Science, 616(1), 10-30.

Arseniev, D. G., Belyaevskaya, E. A., Denisova, V. A., \& Vrublevskaya, M. V. (2016). Efficacy analysis of instruments and tools of attracting foreign students to university educational programs. University Management: Practice and Analysis, 6, 44-53.

Ashirbagina, N. L., \& Frick, O. V. (2016). The image of the university through the eyes of the subjects of the educational process. Actual problems of the humanities and natural sciences, 4, 17-20.

Belousenko, D. V. (2018). Use of social networks in the promotion of educational services. Young scientist, 45, 55-58.

Belyavsky, I. K. (2014). Marketing research: information, analysis, forecast: Textbook. Allowance. Moscow: Prospect. 150.

Bocharov, M. P., \& Chumikov, A. N. (2014). Public Relations: Theory and Practice. Moscow: Delo. 312.

Butkouskaya, V., Llonch-Andreu, J., \& Alarcón-Del-Amo, M. (2019). Strategic antecedents and organisational consequences of IMC in different economy types. Journal of Marketing Communications, 27(2), 115-136.

Carvalho, A., \& Fernandes, T. (2018). Understanding customer brand engagement with virtual social communities: A comprehensive model of drivers, outcomes and moderators. Journal of Marketing Theory and Practice, 26(1-2), 23-37. https://doi.org/10.1080/10696679.2017.1389241

Chapleo, C. (2015). Brands in higher education. International Studies of Management \& Organization, 45(2), 150-163. https://doi.org/10.1080/00208825.2015.1006014

Chapleo, C., \& O'Sullivan, H. (2017). Contemporary thought in higher education marketing. Journal of Marketing for Higher Education, 27(2), 159-161. https://doi.org/10.1080/08841241.2017.1406255

Clement, J. (2020). Facebook: distribution of global audiences 2020, by age and gender. Retrieved from: https://www.statista.com/statistics/376128/facebook-global-user-agedistribution/.

Cordelier, B., Vasquez, C. \& Viviane, S. (2021). Branding the university: building up meaning through ideological oppositions. Journal of Marketing for Higher Education, 31:1, 136154. https://doi.org/10.1080/08841241.2020.1761507

Education and Science activity of Rossotrudnichestvo (2020). Retrieved from: http://rs.gov.ru/en/activities/10 2020

Efthymios, C. \& Zinck Stagno, M. C. (2011). Potential of the social media as instruments of higher education marketing: a segmentation study. Journal of Marketing for Higher Education, 21:1, 7-24. https://doi.org/10.1080/08841241.2011.573593

Elken, M. (2019). Marketing in higher education. In: Encyclopedia of international higher education systems and institutions. Springer Netherlands, 1-5. https://doi.org/10.1007/978-94-017-9553-1_569-1

Kashif, F., Mokhtar, S. S. M.\& Salleh, S. Bt. Md. (2021). Role of brand experience and brand affect in creating brand engagement: a case of higher education institutions (HEIs). Journal of Marketing for Higher Education, 31(1), 107-135. https://doi.org $10.1080 / 08841241.2020 .1759753$

Fomina, E. M., \& Pimonova, S. A. (2018). Growing attractiveness of Russian universities for international students. University Management: Practice and Analysis, 22(4), 97-109. https://doi.org/10.15826/umpa.2018.04.043

Freberg, K. (2020). Social Media for Strategic Communication: Creative Strategies and Research-Based Applications. Journal of Public Relations Education, 6 (2), 200-204. 
Huempfner, L., \& Kopf, D. A. (2017). Using stakeholder marketing and social responsibility for new product development in higher education: A business spanish model. Journal of Marketing for Higher Education, 27(2), 251-273. https://doi.org/10.1080/08841241.2017.1384782

García, H. A., \& Villarreal, M. de L. (2014). The "Redirecting" of International Students: American Higher Education Policy Hindrances and Implications. Journal of International Students, 4(2), 126-136.

Ivanova, I. N., \& Mironova, R. E. (2012). Reintegration relations in the field of education in the post-Soviet space. Povolzhsky trade and economic journal, 3(25), 98-110.

Goi, M., Kalidas, V., \& Yunus, N. (2018). Mediating roles of emotion and experience in the stimulus-organism-response framework in higher education institutions. Journal of $\begin{array}{llll}\text { Marketing for Higher } \quad \text { Education, } & \text { 28(1), }\end{array}$ https://doi.org/10.1080/08841241.2018.1425231

Guilbault, M. (2018). Students as customers in higher education: The (controversial) debate needs to end. Journal of Retailing and Consumer Services, 40, 295-298. https://doi.org/10.1016/j.jretconser.2017.03.006

Jess, L. Gregory, (2019). Applying SERVQUAL: Using service quality perceptions to improve student satisfaction and program image. Journal of Applied Research in Higher Education, 11 (4), 110-115.

Kaushal, V., \& Ali, N. (2020). University Reputation, Brand Attachment and Brand Personality as Antecedents of Student Loyalty: A Study in Higher Education Context. Corporate Reputation Review, Palgrave Macmillan, 23(4), 254-266. https://doi.org/10.1057/s41299019-00084-y

Kerr, G., \& Kelly, L. (2017). IMC education and digital disruption. European Journal of Marketing, 51(3), 406-420. https://doi.org/10.1108/EJM-08-2015-0603

Korchagova, L. A. (2019). Promotion analysis of the universities on social networks. RSUH/RGGU Bulletin. "Economics. Management. Law" Series; 1, 31-43. https://doi.org/10.28995/2073-6304-2019-1-31-43

Levina, S. A. (2015). Integrated Marketing Communications Application in the Education Market. Management consulting, 6, 173-181.

Mahoney, J. (2013). Strategic Communication: Principles and Practice. Melbourne: Oxford University Press. 260.

Melikyan, A. V. (2016). Typology of international educational activities of Russian universities. Higher education in Russia, 12(207), 140-150.

Neretina, E. A., \& Makarets, A. B. (2009). University website as an important tool of marketing communications. Bulletin of the South Ural State University. Series: Economics and Management, 41 (12), 85-94.

Ong, C. H., Lee, H. W., \& Ramayah, T. (2018). Impact of brand experience on loyalty. Journal of Hospitality Marketing \& Management, 27(7), 755-774. https://doi.org/10.1080/19368623.2018.1445055

Qiao, L., Song, M., \& Wang, N. T. (2019). Virtual Brand Community Experience, Identification, and Electronic Word-of-mouth. Journal of Computer Information Systems, 61(4), 1-14. https://doi.org/10.1080/08874417.2019.1661805

Potdar, V., Joshi, S., Harish, R., Baskerville, R., \& Wongthongtham, P. (2018). A process model for identifying online customer engagement patterns on Facebook brand pages. Information Technology \& People, 31(2), 595-614. https://doi.org/10.1108/ITP-02-20170035

Pyankova, S. G., Mitrofanova, I. V., Ergunova, O. T., \& Zhemerikina, E. B., (2020). Promotion of a Higher EducationInstitution in the Educational Services' Market Under the 
Conditions of Spatial Integration of Universities. Regional Economy. South of Russia, 8 (3), 34-51. https://doi.org/10.15688/re.volsu.2020.3.4

Prentice, C., Wang, X., \& Loureiro, S. M. (2019). The influence of brand experience and service quality on customer engagement. Journal of Retailing and Consumer Services, 50, 5059. https://doi.org/10.1016/j.jretconser.2019.04.020

QS World University Rankings (2021). Retrieved from: https://www.topuniversities.com/university-rankings/world-university-rankings/2021

Rodríguez, G. C., Román, C. P., \& Zúñiga-Vicente, J.Á. (2019). The relationship between identification and loyalty in a public university: Are there differences between (the perceptions) professors and graduates? European Research on Management and Business Economics, 25(3), 122-128. https://doi.org/10.1016/j.iedeen.2019.04.005

Salgado, E. G., \& Vela, M. R. (2019). Brand Fan pages experience and strength as antecedents to engagement and intensity of use to achieve HEIS' brand loyalty. Journal of Marketing for Higher Education, 29(1), 102-120. https://doi.org/10.1080/08841241.2019.1605437

Shahsavar, T., \& Sudzina, F. (2017). Student satisfaction and loyalty in Denmark: Application of EPSI methodology. PLOS ONE, 12(12). https://doi.org/10.1371/journal.pone.0189576

Salamatov, A. A., Korneev, D. N., Demtsura, S. S., Plohotnyuk, E. B. Kostryukova, L. A., Simonyan, R. Y., ...Apukhtin, A. S. (2012). Marketing activities of a vocational education institution. A. A. Salamatov (Eds.). Chelyabinsk: Chelyabinsk State Pedagogical University. 104.

Schulz, S. A. (2006). Mastering the admissions game: understanding the enrollment priorities and recruitment strategies of master's institutions. Electronic dissertation. Arizona: The University of Arizona. Retrieved from: https://repository.arizona.edu/handle/ 10150/194679.

Shurair, A. S., \& Pokharel, S. (2019). Stakeholder's perception of service quality: A case in Qatar. Quality Assurance in Education, 27(4), 493-510. https://doi.org/10.1108/qae-052017-0023

Sim, M., Conduit, J., \& Plewa, C. (2018). Engagement within a service system: A fuzzy set analysis in a higher education setting. Journal of Service Management, 29(3), 422-442. https://doi.org/10.1108/JOSM-08-2016-0232

Simon, C., Brexendorf, T. O., \& Fassnacht, M. (2013). Creating online brand experience on Facebook. Marketing Review St. Gallen, 30(6), 50-59. https://doi.org/10.1365/s11621013-0299-6

Simon, F., \& Tossan, V. (2018). Does brand-consumer social sharing matter? A relational framework of customer engagement to brand-hosted social media. Journal of Business Research, 85, 175-184. https://doi.org/10.1016/j.jbusres.2017.12.050

Strydom, J., Jooste, C., \& Cant, M. (2000). Marketing management (4th ed.). Cape Town: Juta. 350 .

Yoshida, M., Gordon, B. S., Nakazawa, M., Shibuya, S., \& Fujiwara, N. (2018). Bridging the gap between social media and behavioral brand loyalty. Electronic Commerce Research and Applications, 28, 208-218. https://doi.org/10.1016/j.elerap.2018.02.005

Yuzhakova, T. A., \& Karakchieva, I. V. (2015). International student mobility is a tool to increase the country's competitiveness in the international market for educational services. Science, Technology and Education, 5(11), 107-111. 